\title{
Electoral Corruption and Democratic Sustainability in Nigeria
}

\author{
Kia, Bariledum \\ NCE, BA (Hons), M.Sc, Ph.D (In View) Facilitator Open National University Of Nigeria, \\ Port Harcourt Study Centre
}

\begin{abstract}
This paper examines the effect of Electoral fraud on sustainable democracy in Nigeria. In carrying out this work, descriptive method and Marxian political economy paradigm was employed as the framework of analysis. It was found out among others that electoral fraud undermines participatory democracy. Thus, the input of the people in deciding who rule them is scuttled; popular participation in governance and elections of public officers have been hijacked by political gladiators, god-fathers and god-mothers. Consequently the nations democratic practice appear unstable. To avert this, the paper suggests a total over haul of social structures.
\end{abstract}

\section{Introduction:}

One of the key strikes in the socio-political arena today revolves around the quest for the system of government that will guarantee peace, settled development and orderly changes in government. Nigerians who had lived under military dictatorship for several years apparently found democracy suitable to their needs, it was therefore a welcomed development when in 1999 Nigeria returned to democratic rule. The popular view about democracy in Nigeria is that, it is a preferred regime above authoritarian alternative (The Comet, 2005). Democracy in a complex society writes Lipset (1963), is a political system which supplies regular constitutional opportunities for changing the governing officials and social mechanism which permits the largest possible part of the population to influence major decisions by choosing among contenders for political office. From Lipset's view, there are two major important factors characterizing the concept of democracy, and these are;

1. Efficient electoral system which brings people into office and which gets people out of office.

2. The principle of representative government.

In this sense, election is a prima facie feature of any democracy. This therefore implies that the people's preference to choose their leader in regular, free and fair election is a minimum requirement to sustain democracy. As rightly noted by Nnaa (1985), the electoral system of any nation is the bedrock of its national politics, the decider of how the leaders are chosen as well as the spring board for political development and progress for the society at large. Malfunctioning electoral system is caused by incidence of electoral fraud which inadvertently produces maladministration and stultifies development. In Nigeria, the 1959, 1964, 1983, 1999, 2003 and 2007 general elections revealed that electoral fraud has been internalize and institutionalized in the electoral process, hence the epileptic political development in the country. This paper will, therefore, look at the incidence of electoral fraud at different stages of the electoral process; the time of preparation for election, the conduct of election, post election period, and its attendant consequences on the smooth and successful democratization of Nigeria political system and its sustainability. To have a proper understanding of the subject matter, the paper will state the problem under study, and explain the theoretical framework employed in this study, and shall also attempt a conceptual clarification of terms that will be useful in this study and these include electoral fraud and sustainable democracy. The paper will suggest recommendations to avert the incidence of electoral misconduct and propel the growth of sustainable democracy.

\section{Statement Of Problem}

Election in Nigeria has been characterized by absence of popular participation in the political process, corruption, lack of responsiveness and accountability by those who rule. The political class, civil society, domestic and international monitors, believed that the 2003 and 2007 general elections more than the case in 1999, suffered severe manipulation, such that elections results in some places do not present the true voting pattern (This Day, June 20, 2007, Vanguard, July 12, 2007; The week, July 24, 2007; Gani, 2007; Akande 2007; Adesina, 2006). We are currently faced with court cases resulting from infamous election procedures, charges of corruption, fraudulent enrichment of those in power and the uninspiring conduct of some legislators who are expected to provide the positive support for effective policy that will guarantee sustainable democracy. We are also faced with increasing conflict, among the capitalist class resulting from their competition for more acquisition of national wealth and this is done with clear disregard for democratic values. These situations 
strikes an urgent and compelling though in the heart of every dedicated Nigerian who has watched Nigeria escaped from the clutches of military dictatorship only to land into scandalous politics of professional electoral fraud. It would be recalled that one of the reasons advanced for the military intervention in 1983 was that, elections of that year were massively rigged. Nigeria masses felt out raged that something must be done by every body to save democratic institution and process from the reactionary forces.

The fundamental questions implied by the foregoing are; what electoral fraud really is and why are we concerned with its unproductive effect?, what sustainable democracy really is and why is our present democratic process appears to be unsustainable? what political values can sustain valid democracy in Nigeria and how and how can these values be cultivated?

\section{Theoretical Framework}

We cannot deal with the thought provoking questions raised and perhaps achieve the enduring significance of the subject matter of this discourse without a theoretical focus. In a serious discourse of this nature, it is necessary to make our theoretical framework clear, so that participants will be able to have a focus and perspective of the further development of this discussion. The theoretical exposition for this study is based on Marxian political economy approach. This theory basically arose in reaction to the western liberal theory of state, which inter alia contends that the state is impartial, and independence force, as well as a neutral umpire that caters for the main interest of every member of the society (Okolie, 2009). The Marxian political economy approach deals with the general laws of development and production of material wealth (Ikpe, 2000). Thus, one can situate the paradigm within the primacy of physical needs of man, such as food, cloth, shelter and other material needs that exist in the society. The importance attached to material condition has created two dialectical socio-economic classes-the 'bourgeoisie', the 'haves' and the 'have-not'. Given these two classes in the society, it is imperative to state that electoral fraud in Nigeria is as a result of the country's operation and practice of the tenets of capitalism that breeds class distinction. In Nigeria, the competition for material wealth has taken a central stage and the only means of achieving this goal is through politics. This is because all forms of capitalist operations revolve around politics. The politics of the ruling class has created ties of relationship at all levels of governance in the country. Consequently, the attitude of protecting this links had led to various forms of electoral fraud just to attain power to consolidate their selfish plans and intensions, including the projection of their patron's interest. The quest for material benefits has led to hash competition in the nation's body polity. Thus, electoral frauds have become the order of the day.

As argued by Ekekwe (1986), the periphery of capitalism, that is level of development of the productive forces make the state, through its several institutions and apparatuses, a direct instrument of accumulation for the dominant class or its agencies. Given the low level of development of productive forces, the ruling class christened godfathers uses their economic advantages, social networks and political clouts and cleavages to influence and often determine the course of political process. The prevalence of poverty and high illiteracy rate further enhance their capacities and capabilities to impose political leadership on the helpless, ignorant impoverished masses. Such god fathers have at their disposal instruments of violence which they unleashed on the citizenry and deprive the latter of their rights to choose their political leaders. Indeed, the dominant elements whose basic qualification remains extreme parasitism use the apparatus of the state to commit acts of electoral fraud, criminality and deprivation. Thus, elections are merely used to rationalize existing disempowerment, and the ballot box now becomes a symbolic means of legalizing illegality and renders participating democracy ineffectual. The unity of the approach is that we are able to come down from the peak of abstraction to the concrete explanation of the sources of electoral fraud and how it is being perpetrated and for whom (i.e. the benefactors).

\section{Electoral Fraud And Incidence Of Fraud In Nigeria}

By electoral fraud, we refer to illegal interference with the process of an election. According to Wikipedia (2009), act of electoral fraud tend to involve actions affecting vote counts to bring about a desire election outcome, depressing the vote share of the rival candidates or both. Indeed, many kinds of voter fraud are outlawed in specific electoral legislation, but others are in violation of more general laws such as those banning assault, harassment or rebel (Okolie, 2009). The term electoral fraud also covers acts which although legal, but are considered to be morally unacceptable outside the spirit of electoral law or in violation of the principle of democracy (Wikipedia 2009). The above conceptions of electoral fraud corroborate the view of the Nnaa (1985) who conceived electoral fraud as any dishonest act inimical to the societal acceptable standards of doing things with the ultimate aim of influencing the outcome of election results to one's favour. Electoral fund, in this sense means the act of dishonesty and unconventional method or technical practice adopted in the electoral processes with the intent to influence the outcome or results of elections to one's advantage against the popular will of the people. Electoral fraud occurs at all stages in the democratic process. 


\section{Electoral Fraud At The Stage Of Electoral Preparation}

Electoral frauds committed prior to the conduct of election include;

$>$ Appointment of electoral officers who are loyal to the power that be;

$>$ Malpractices during registration of voters exercise in the form of falsifying registration documents and voters cards.

$>$ Inflating names of voters in areas thought to be one's stronghold, while under registering in opponents' constituencies.

$>$ Multiple registration

$>$ Disqualification of candidate in opposition

$>$ Denial of opponents the right to express their feelings through restructuring the usage of media houses

$>$ Denial of freedom of movement and threat to life of opponent and in some extreme cases assassination or outright imprisonment (Nnaa, 1985; Okolie 2009).

\section{Fraud Committed During Election}

Cooperation between politicians and officers of he Electoral commission (presiding officers, supervisory presiding officers, ward returning officers and polling clerks) as these adhoc staff of the commission act under the influence of material inducements such as money, food and drinks and promise of appointment into positions of trust in government. They stock ballot boxes with illegal voters as they tick the names of voters and hired agents for thumb printing. In some cases, voting centres are shifted from original designated area to a private house or residence where people would locked themselves up thump-printing ballot papers.

Police abets fraud during elections as they give some candidates advantages over their opponents. Touts and "Area boys" are recruited to harass and intimidates electorates in opponent's areas so as to influence the election in favour of their candidates.

\section{Post Election Fraud}

Falsification of election results from various centres at the collection centres.

Declaration of fake results by electoral officers

Politicians connived with some-judges to thwart any objection that will be in their riggers' favour.

\section{Incidence Of Electoral Fraud In Nigeria}

Electoral fraud in Nigeria has gone through sophisticated refinements since 1959. Such that a discussion on Nigeria's electoral process without analysis of this phenomena (fraud) would be deemed as abstract and unrealistic. Ademoyega (1981) and Anifowose (1984) demonstrated in their works the electoral problems that bedeviled the process of democratization in Nigeria before and after independence. Population census has been the basis of election in Nigeria and the malpractices in the conduct of population count have direct consequence in the electoral process. For example, the 1963 population which has been the basis of elections conducted in Nigeria was not devoid of controversy. It was alleged in the South that the Northern region counted cow heads to swell their population. It was this same population that was used for the 1964 general election. The effect of it was the seizure of power in 1966 by the military on account of election fraud and abuse of power (Nnaa, 1985).

The 1964 election was boycotted by the opposition party, United Progressive Grand Alliance (UPGA) in protest against gross abuses and lawlessness perpetrated in the political process by the incumbent Nigeria National Alliance (NNA). The elections that were later conducted in the boycotted areas were recorded with gross abuses and irregularities. After the 1964 elections, came the 1965 western region election. The electoral frauds that were committed remained indelible in the annals of Nigeria history. Corroborating this fact, Esua, E.E. (then the Head of Federal Electoral Commission (FEDECO) cited in Nnaa (1985) had it that some electoral officers were not only kidnapped, but equally prevented from discharging their duties. Electoral fraudsters were not contended with merely studding ballot boxes with ballot papers. They also took over FEDECO offices and Radio station and announce fake results to the electorates. It was the political turbulent born of massive electoral fraud as earlier mentioned that brought in the military in 1966. The second civilian journey in the politics of Nigeria also witnessed electoral rigging. Although electoral fraud was not reported on large scale, the 1979 election according to Nnaa (1985) witnessed registration frauds and other irregularities and allegation of electoral frauds came from various quarters ranging from mischievous electoral officers who prevented people from voting; complaints of insufficient ballot papers in some quarters and extra in other areas. Some of these allegations became subject of court litigations as was the case of presidential election tussle between Shehu Shagari and late Obafemi Awolowo.

The 1983 August - September general elections were attended with electoral fraud on the bizarre scale with crude and modern sophisticated political techniques. It started with the appointment of FEDECO Chairman Justice Ovie-Whiskey. This appointment was seen to be based on party affiliation and sympathy. Secondly, 
there was outrageous quadruplication of figures of registered voters. For example, it was unthinkable to observe that the old Rivers State with a total population of between 1.5 and 2.5 million had over 3 million registered voters by 1983. Similar unacceptable figures were recorded for other states (The Daily Times, Saturday $5^{\text {th }}$ November, 1983). Thirdly, the way FEDECO went about the actual conduct of the election left much to be desired. The Daily Times publication (1983) stated that the election witnessed massive electoral fraud. Prof. Ola Rotimi in Daily Times, decries on the electoral fraud said "the Federal Government had rather preferred the play host to electoral provision that had raised fraud, cheating and armed coercion to heigh of glory".

The institution of the state such as the Police Force which was supposed to check the excesses of political parties and those of FEDECO officials did not help matters. It was also the case in the April, 2003 and 2007 general elections. The genesis of electoral graud in recent times is rooted in the 1999 constitution which allows the incumbent to re-contest for political position without resignation. The ruling people Democratic Party (PDP) cash in on this unpopular clause which does not suit the political terrain of developing nations like ours, and manipulated the electoral process. The results is a brand of democracy nick-named "carry go", 'return". The results of both elections generated a lot of controversy as figures of both elections did not reflect the true nature of the voting pattern. And not even one of the political parties can justify claim to have conducted itself without blemished. In the election there was sufficient evidence of brazen and Cynical fraud to suggest that they all approached the elections without much faith in themselves or in the electorates. The 2007 general elections Okolie (2009) posited were characterized by monumental fraud. Like previous elections in Nigeria, the 2007

was characterized by:

$>$ Late arrival of electoral materials in the various polling units.

$>$ Inadequate polling materials

$>$ Voter's registration problems

$>$ No secrecy of the ballot

$>$ Ballot paper problems

$>$ Snatching of ballot boxes and destruction of ballot materials

$>$ Violence

$>$ Use of security agencies to intimidate the voters and rigged elections.

$>$ No voting in some polling centres

Use of government officials to commit electoral fraud

$>$ Omissions of some parties' logo and candidate names on the ballot paper to disenfranchise their opponents supporters.

IV. Incidence Of Political Predicated Killings In Nigeria 1999 - 2010

\begin{tabular}{|c|c|c|c|}
\hline DATE & NAME & POSITION & $\begin{array}{c}\text { CIRCUMSTAN } \\
\text { CE } \\
\end{array}$ \\
\hline $18 / 04 / 001$ & Eze-Odimegwu Okowkwo & Chieftain of ANPP, Anambra & Murdered \\
\hline $19 / 04 / 001$ & Hon. Monday Ndor & Member - Rivers State House of Assembly & Murdered \\
\hline $23 / 08 / / 09$ & $\begin{array}{l}\text { Chibueze Idah Ogbonna Odimbaire \& } \\
\text { Ifeanyi }\end{array}$ & All members of PDP in Ebonyi State & Murdered \\
\hline $29 / 08 / 001$ & Victor Nwankwo & $\begin{array}{l}\text { A younger brother of Arthur Nwankwo founder Eastern } \\
\text { mandate }\end{array}$ & Murdered \\
\hline $9 / 12 / 001$ & Hon. Odunayo Olagbaju & Member-Osun State House of Assembly & Murdered \\
\hline $23 / 12 / 001$ & Chief Bola Ige & $\begin{array}{l}\text { The Attorney General of the Federation \& Ministry of } \\
\text { Justices }\end{array}$ & Murdered \\
\hline $5 / 08 / 002$ & Ahmed Pategi & Chairman PDP Kwawa State & Murdered \\
\hline $01 / 09 / 002$ & Bar. Barnabas Igwe and his wife & Chairman Nig. Bar Ass. Anambra State & Murdered \\
\hline $08 / 02 / 003$ & Ogbonnaya Uche & $\begin{array}{l}\text { Contestant on the platform of ANPP Imo State-Senatorial } \\
\text { candidate }\end{array}$ & Murdered \\
\hline $0 / 03 / 003$ & E. Emenike & Chieftain of ANPP Imo State & Murdered \\
\hline $0 / 02 / 003$ & Theodere Agwatu & Prin. Sec. to Imo State Government & $\begin{array}{l}\text { Murdered at } \\
\text { her residence }\end{array}$ \\
\hline $5 / 03 / 003$ & Harry Marshall & National Vice Chairman of ANPP & $\begin{array}{l}\text { Murdered at his } \\
\text { residence }\end{array}$ \\
\hline $0 / 03 / 002$ & Rasak Ibrahim & Supporter of former Governor of Kwara State, Lawal & $\begin{array}{l}\text { Murdered } \\
\text { along the Road }\end{array}$ \\
\hline $1 / 03 / 003$ & Hon. Anthony Nwudo & ANPP House Assembly Candidate in Ebonyi State & $\begin{array}{l}\text { Murdered in } \\
\text { Abakanki }\end{array}$ \\
\hline $9 / 04 / 003$ & Onyewuchi Iwuchukwu & ANPP Stilwart-Imo State & $\begin{array}{l}\text { Murdered in } \\
\text { Ikeduru }\end{array}$ \\
\hline $0 / 04 / 003$ & Toni Dimeqwu & Vocal member in Imo State House of Assembly & Murdered \\
\hline $2 / 05 / 003$ & 15 person & Delta State & $\begin{array}{l}\text { Killed in a } \\
\text { political Rally }\end{array}$ \\
\hline $4 / 03 / 004$ & Aminasoari Dikibo & National Vice Chairman of PDP South South & Killed on his \\
\hline
\end{tabular}


Electoral Corruption And Democratic Sustainability In Nigeria

\begin{tabular}{|c|c|c|c|}
\hline & & & $\begin{array}{l}\text { way to Delta } \\
\text { State }\end{array}$ \\
\hline $03 / 03 / 004$ & Andrew Agom & Member board of Trustee of PDP and his Police & $\begin{array}{l}\text { Killed on their } \\
\text { way to Abuja }\end{array}$ \\
\hline $01 / 03 / 004$ & Philip Olotumpa & Resident Electoral Commissioner Kogi State & $\begin{array}{l}\text { Murdered in his } \\
\text { Residence }\end{array}$ \\
\hline $15 / 05 / 005$ & Alibi Olajoku & Political Associates of Commissioner of Works-Lagos State & $\begin{array}{l}\text { Murdered on the } \\
\text { Road }\end{array}$ \\
\hline $27 / 07 / 005$ & Anthony Ozioko & Assistant National Director; Research and planning & $\begin{array}{l}\text { Murdered in his } \\
\text { Residence }\end{array}$ \\
\hline $30 / 06 / 006$ & Jesse Arukwu & $\begin{array}{l}\text { Governorship aspirant on the platform of Adv. Congress } \\
\text { Democrats ACD }\end{array}$ & $\begin{array}{l}\text { Murdered in his } \\
\text { residence }\end{array}$ \\
\hline 2008 & $\begin{array}{l}\text { Engr. Eman Ekpenyong - Mr. Mathias } \\
\text { Ekpenyong Akwa Ibom }\end{array}$ & PDP Start works in Uyo LGA & $\begin{array}{l}\text { Murdered in } \\
\text { their Business } \\
\text { premises }\end{array}$ \\
\hline 2009 & Miss Philomena Udonung & The mother of a PDP Governorship Aspirant & $\begin{array}{l}\text { Kidnapped and } \\
\text { murdered after } \\
\text { even after } \\
\text { ransomed was } \\
\text { paid }\end{array}$ \\
\hline 2009 & Chief Paul Inyang & $\begin{array}{l}\text { PDP Starlwart and a contestant for the State chairmanship } \\
\text { position }\end{array}$ & $\begin{array}{l}\text { Murdered in the } \\
\text { church }\end{array}$ \\
\hline $1 / 02 / 009$ & Elder Nse Ikpe & PDP Starlwart-Uyo L.G.A. & Kidnapped \\
\hline$\$ 1 / 01 / 010$ & Gen. Edet Kpan Rtd & Former Director, NYSC & $\begin{array}{l}\text { Kidnapped in the } \\
\text { church and two } \\
\text { other members } \\
\text { of the church } \\
\text { killed during the } \\
\text { process }\end{array}$ \\
\hline $9 / 09 / 1999$ & Sunday Ugwu & $\begin{array}{l}\text { Killed by Gumen who mistook him for his elder brother } \\
\text { Ugwu Nwabueze, a member of the Enugu state House of } \\
\text { Assembly }\end{array}$ & Murdered \\
\hline Dec.2000 & Lai Bohagun & A failure politician and renounced architected & Murdered \\
\hline Feb.4,001 & James Ibon & Then governor of Delta State & $\begin{array}{l}\text { Occupied death } \\
\text { in exchange of } \\
\text { gun fire between } \\
\text { two faction of } \\
\text { PDP }\end{array}$ \\
\hline Mar.1,002 & $\begin{array}{l}\text { Three students reportedly killed at } \\
\text { Effurun Delta State after a P.B.P rally } \\
\text { turned violence }\end{array}$ & & \\
\hline Mar.4,004 & Luke Shugaba & Chairmanship candidate in Bussa LGA, Kogi State & Murdered \\
\hline lly 27,006 & Funsho William & A gubermtorial aspirant of P.D.P in Lagos State & Murdered \\
\hline Aug. 14,006 & Ayo Daramola & A Gubernutorial aspirant of P.D.P in Ekiti State & Murdered \\
\hline Aug.12,002 & Janet Olajake & P.D.P Leader in Odigbo L.G.A Ondo State & Murdered \\
\hline pept.14,007 & Segun Awunesi & $\begin{array}{l}\text { Former Chief Security officer to Olusegu Agagu, Ondo State } \\
\text { Governor }\end{array}$ & Murdered \\
\hline
\end{tabular}

The wanton political violence and the assassination of political opponents in Nigeria as a re-occurring event gives the impression that democracy has degenerated and its survival uncertain.

\begin{tabular}{|l|l|l|}
\hline \multicolumn{1}{|c|}{ STATE } & \multicolumn{1}{|c|}{ GOVERNORS REMOVED BY LAW } & \multicolumn{1}{c|}{ REPLACED GOVERNORS } \\
\hline Osun State & Prince Oyiwola (P.D.P) & Rauf-Arcgbesola (A.C.N) \\
\hline Edo State & Prof. Osungbor (P.D.P) & Com. Adamus Oshomore (A.C.N) \\
\hline Ekiti State & Dr. Segun Oni & Br. Kayode Fayenu (A.C.N) \\
\hline Ondo State & Olusegun Agagi (P.D.P) & Mimiko Labour Party \\
\hline Anambra State & Dr. Chris Ngige (P.D.P) & Peton Obi - APGA \\
\hline Rivers State & Celestine Omehia (P.D.P) wrongly substituted & Rotimi Amaechi (P.D.P) \\
\hline
\end{tabular}

Source: New watch magazine august, 14 2006, Tell Magazine 2010

Court ordered for re-run election following the nullification of the result on the ground of electoral fraud in many states. Among others include, Cross River, Delta State, Kogi State, Katsina State, Adamawa State, Sokoto State and Bayelsa State.

The situation above implies that most of the acclaimed winers in the various elected positions are not the authentic choice of the voters and votes in election handly court. As a corollary to the above, electoral fraud, sharp practices and criminality pervades the political landscape of Nigeria and rendered democracy ineffectual and outlandish. In its present form and structure, Nigeria governance is incapable of ensuring competitive and integrity-driven electoral process, thus the nation's democracy appears unsustainable. 


\section{Sustainability Of Democracy In Nigeria}

Theoretically, when democracy is considered from the people based angle, its sustainability can simply be assumed. The reason being that, since it is people driven then it is expected that the people should guide and sustain it. In this sense, sustainable democracy is concerned with efforts made or being made to properly manage, protect and guide the democratic system of organizing the state so as to ensure that the principles are respected, its structures made functional to deliver its development objectives to the people (Ndelifru, 2007).

To sustain democracy requires developing the right firms of framework that will motivate the people to be committed to the system. This paper discusses three basic principles that can consolidate the nation's democratic practice.

\section{Rule Of Law}

Rule of law in the sense of democratic development encompasses supremacy of the constitution, Fundamental Human Rights and dependable independent judiciary, if these are properly fixed, behavioural and institutional practices would normalized democratic policy. In countries like Ghana, US and South Africa, rule of law steer the entire sectors. Strict, adherence or observance of rule of law will ensure the coordination, cultivation and inculcation in the citizenry, a democratic behaviour of service, commitment to the people' welfare, high sense of civil responsibility, trusteeship, spirit of fair policy and tolerance. All these features are critical to democratic sustainability. The practice of rule of law will guarantee human rights, accountability, empowerment and functional civil society.

\section{People Sovereignty}

When power is derived through free and fair election that reflect the consent of the governed and perhaps revert back to the citizenry if abuse democratic sustainability is certain. This, is because, the governed is empowered to use their votes to pass judgement on the performance or otherwise of the executives. this way, government that has itself elected in free and fair election but perform poorly will be defected in subsequent contest, and result accepted by the incumbent executive. Doing this will institutionalize participatory democracy and discourages political activities undertaken for private accumulation of wealth at the expense of the masses. Also, only individuals of proven integrity in both private and public lives will have access to state power. It is only in this way that legitimation of government can be guarantee.

\section{Evolution Development - Driven Base Party System}

At the moment, Nigeria's political parties serve as mere platforms for gaining access to power and do not have links with the society's social basis. Democracy cannot be consolidated without developing the right structures and practice of political parties. Internal workings of political parties have to be rooted in generally accepted norms and values to allow an evolution of a party system that will reflect the dynamics of socio-political and economic interests of the masses. This will not only enhance development but equally ensure that political parties play according to rules, or code of conduct.

\section{References}

[1] Adesina, A. (2006). Elections Reforms Overview and Issues: Costa Ria Helen Kallog Congressional Review Service.

[2] Ademoga, A. (1981) Why we struck. Enugu: Fourth Dimension Publication. Agbaje, A. (2004). Politics and Information Management: The need for

[3] Political stability. Paper presented in a Media Forum in Lagos. Akande, T. (2001). The Mean of Manipulation of Journal of Democracy Vol. 3. Aba: APPA Publication.

[4] Anifowose, R. (1984). Politics and Violence in Nigeria, access on http/www.info.com 07/06/2011

[5] Ayi, L. (1998). Is the Third Wave of Democratization Over? The imperative of Consolidation. Costa Rica: Hellen Kallogg Institute working paper No. 237.

[6] Deegan, S. (2003). Democratic Institutional Reforms and Political Conflict: Evaluating Alternative Explanations of Electoral Reforms: Costa Rica: Hellen Kallogg Congressional Review services.

[7] Diamond, L. (2003). How solid is man's support for Democracy. Lagos Larry Press. Ekekwe, E. (1986): Class and State in Nigeria, Lagos: Longman.

[8] Gani, F. (2007). Party Politics and Electoral Reforms: How are the changes Being effected in African Journal of Democracy, Vol. 6, No. 7

[9] Ikpe, U. B. (2000). Political Behaviour and Electoral Politics in Nigeria: A

[10] Political Economic Interpretation, Uyo: Golden Educational Publishers. Lipset, S. (1963). Political Man: The Social Basis of Politics, New York: Anchor Books.

[11] Nnaa, B. G. (1985). The Election and Incidence of Rigging. Undergraduate Seminar, University of Port Harcourt. Ndehfru, J. (2007). "Good Government and Challenges of Democratic Sustainability" in Policy Alert, Vol. 1 No. 1 Aba, APPA Publication.

[12] Okolie, A. M. (2009). "The State, Electoral Fraud and the Illusion of Participatory Democracy in Africa: Lessons from the 2007 General Elections in Nigeria in Nigerian” Journal of International Affairs: Lagos: NIIA Publication.

[13] Salami, M. T. (2001). "Democratic Development 1990-2000: An Overview" in Journal of Rights and Democracy. Lagos: 1 CHRDD Publication.

[14] Udo, E. (2002). "Democracy as a pragmatic ideology" in Uyo Journals of Humanities. A publication of the Faculty of Art, University of Uyo. UNDP Country Report (1997). 
[15] The Comet (2005) South Africa: Election System and Conflict Management, PP. 22, 26 The Daily Times Nigeria (1984). Election 1983 Times Press, p. 17

[16] This Day (2007). The Role of Electoral Administration in Democratic Transition, p. 23

[17] Vanguard (2007) Practical Advice for Electoral System Designers in Administration and cost of Elections Project, p. 91.

[18] The Week (2007). Tentative Qualitative Criteria for Measuring the Progress Democracy and Good Government in Africa, p. 56.

[19] Tell Magazine (2010). The Taming god-fatherism p. 14 